\title{
Erratum to: Peroral endoscopic removal: as a minimally invasive long-term surgical treatment of a regurgitated giant polisegmented fibrovascular polyp of the esophagus
}

László Iván · Róbert Paczona • Károly Szentpáli • József Jóri

Published online: 26 September 2010

(C) Springer-Verlag 2010

Erratum to: Eur Arch Otorhinolaryngol (2009)

266:1031-1034

DOI 10.1007/s00405-008-0766-x

This article has been retracted because of duplicate publication in different journals.

The online version of the original article can be found under doi:10.1007/s00405-008-0766-x.

L. Iván $(\bowtie) \cdot$ R. Paczona · J. Jóri

Department of Oto-Rhino-Laryngology and Head and Neck Surgery, University of Szeged, 6725 Szeged, Hungary

e-mail: Ivan@ORL.SZOTE.U-Szeged.hu

K. Szentpáli

Department of Surgery, University of Szeged, Szeged, Hungary 